\title{
Public Fundraising for Financing Islamic Education and Dakwa Mission
}

\author{
M. Falikul Isbah \\ Gadjah Mada University, Yogyakarta \\ email:falikul.isbah@ugm.ac.id
}

\begin{abstract}
Studies on Islamic education and Islamic propagation (dakwa) have not addressed the aspect of how particular actors fund their missions in Islamic education and dakwa. Based on a case study at Hidayatullah Islamic boarding school or Pesantren Hidayatullah, this article tries to correlate the issue of public fundraising and the financing of Islamic education and dakwa mission in contemporary Indonesia. Pesantren Hidayatullah conducts public fundraising program by forming a charity organization, namely Baitul Maal Hidayatullah (BMH). The finding reveals that the majority of the fund raised from public is used to finance Hidayatullah's schools and dakwa missions. This finding is in contrast to what have been suggested by other studies stating that charitable fund is supposed to be distributed back to the community based on the need criteria.
\end{abstract}

Keywords:

Public Fundrising, Islamic Education, Dakwa'

\section{Introduction}

Most studies on Islamic education and Islamic propagation (dakwa) have not addressed the aspect of how particular actors fund their missions in Islamic education and dakwa (eq. (Azra, Azyumardi, Dina Afrianty 2007); (Damopoli 2011); (Husin 1998); (Hefner 2009); (Isbah 2012); (Jackson 2008). Using an empirical finding from a case study at Pesantren Hidayatullah, Balikpapan, this article tries to correlate the issue of public 
fundraising and the financing of Islamic education and dakwa mission in contemporary Indonesia. Pesantren Hidayatullah is located in Balikpapan, East Kalimantan. This pesantren has systematically raised alms-giving funds from the public through its charity organization, Baitul Maal Hidayatullah $(\mathrm{BMH})$, for more than a decade. The funds collected have progressed along with its further outreach in conducting dakwa mission. The more congregations they are able to organize, the more funds they are able to collect. The funds are then allocated mostly for financing its education and dakwa mission. I argue that there is a cycle of education, dakwa, and fundraising within Hidayatullah's activities. Each of the three fields shapes the others.

This article is organized into five sections. The first section provides a historical overview of Hidayatullah, from a small Islamic study group into an Islamic boarding school which is then developed as a mass organization with hundreds of branches throughout the archipelago. The second section uncovers the dynamic development of Hidayatullah in Balikpapan, specifically with its institutions and dakwa mission. Hidayatullah's efforts to initiate revenue generating business is then discussed to demonstrate Hidayatullah's efforts in financing its education and dakwa mission. The fourth section is about the most important money machine of the movement: Baitul Maal Hidayatullah (BMH). It can be said that this charity organization is a resource to obtain funds from public, but not to distribute them. This is in contrast to what have been suggested by other studies stating that charitable fund is supposed to be distributed back to the community based on the need criteria (eq. Helmanita; Isbah 2016, Chapter 4). The final section shows where the fund goes as to meet the movement's main mission: education and dakwa.

DINIKA, Volume 3, Number I, January - April 2018 


\section{The History of Hidayatullah}

Pesantren Hidayatullah is located in Gunung Tembak, about 30 kilometers from Balikpapan, an important business city in East Kalimantan. It was founded in 1973 as a further development of dakwa activities led by the late Abdullah Said. Initially, Said started his dakwa movement in the inner city of Balikpapan, but eventually he moved his main activities in Gunung Tembak for the sake of an ampler space. Unlike other pesantren, the complex of Hidayatullah is not designed only as an education center but also as a dwelling or Islamic-based neighborhood. On the land of more than 50 hectares, there is not only school and dormitory buildings but also hundreds of permanent houses which accommodate the so-called dakwa cadres with their families. Such a design is intended as an effort to build a true "Muslim Umma" based on Islamic sharia. During my fieldwork, there were about 800 male and 600 females students who live within a separated area. The numbers of families living in medium-size houses were about 300 families. There was a very strict separation between male access area and female-only access area. The whole residents of the complex must adjust to the Islamic rules, such as every male has to attend the collective prayer five times a day in the mosque.

It is important to understand that Hidayatullah has transformed to be a mass organization since 2000. The story begun from the dakwa strategy of Abdulllah Said to create a true Muslim umma based on the Islamic sharia. For this aim, he initiated both sermons for general public and lectures for limited participants who were eventually recognized as his dakwa cadres. The latter model is called dakwa training. When he saw the cadres had been matured on their Islamic sciences and dakwa spirit, he asked the cadres to move to remote places. The range of the Islamic propagation done by Hidayatullah at that time was from inland Kalimantan to mountainous Papua. Wherever the cadres were delegated, they bounded and identified themselves as Hidayatullah dakwa warriors. 
They saw Abdullah Said as their great teacher and leader because their mission is not only to spread Islamic messages but also to build an ideal Muslim umma under the guidance of Abdullah Said. When Abdullah Said died in 1998, there were unease about the direction of their dakwa movement. They eventually came to a convention of transforming the network into a mass organization in 2000. At that time, the spread of the dakwa cadres had been in more than 200 districts (kabupaten) which were then converted to be branches of the organization. Each branch has around 100 dakwa cadres.

In its organisation profile, Hidayatullah states that its main focus is in dakwa and education. ${ }^{1}$ The dakwa mission is conducted through sending preachers to many regions, especially to remote areas throughout the country. There are some books documented its dakwa outreach in small island (Latief 2012), in mountainous and remote islands. Another mean of dakwa done by Hidayatullah is its monthly magazine Suara Hidayatullah.

The magazine Suara Hidayatullah started in early 1980s as a modest monthly bulletin in which the regular content is Abdullah Said's essays and the summary of his lectures. The magazine, according to one of its former editors, has a good finance as its average revenue from advertisement is around Rp. 200.000.000,- for each issue. The reason behind this is that Suara Hidayatullah is printed 50 thousand copies and distributed in more than 200 districts throughout Indonesia. This is one of the life-longest Islamic print media in Indonesia. With this remarkable distribution outreach, most of the advertisement posters are expected to find re-sellers for their products. The resellers are than expected to carry out the retail sales of the products in their respective regions. According to the former editor, most of advertisement posters are satisfied with their product marketing growth as they are able to reach unpredicted areas without building distribution offices in that regions. ${ }^{2}$

1 http://hidayatullah.or.id/mainstream/

2 Interview with Ahmad Fadlil. Balikpapan, 22 July 2013.

DINIKA, Volume 3, Number I, January - April 2018 
Meanwhile, the education mission is pursued through establishing schools, academies and pesantren or Islamic boarding schools. The stage of establishing Hidayatullah branch in a district is commonly started by establishing an Islamic study group (majlis taklim). When it has successfully attracted support from the local community, Hidayatullah cadres usually follow it up continue the activity by founding a kindergarten. When the kindergarten receives enough students, the cadres then establish Islamic primary school. The same flow lasts continuously up to high school or academy. However, only three of the hundred branches that is able to establish academy. The time needed to pursue the stages is various, depending on the support from local community, the growth of the cadre number in the area, and the potential market of the schools.

Apart from the mission of education, establishing schools is a very strategic movement for Hidayatullah. Given the fact that many Hidayatullah cadres are outsiders who reside in new area; the schools provide them medium to interact with local community. When daily socialization with the local community runs smoothly, further agenda can be pursued easier.

In addition, with the schools, the cadres gain opportunity to earn modest income on which they can survive. In some cities, Hidayatullah schools can be categorized as expensive full day schools such as SMP Luqman Hakim in Surabaya, SMP Al Izzah in Batu, Malang, and the same school in Balikpapan City. The schools targets Muslim middle-upper class who are known to be unsatisfied with the quality of government schools and see such schools providing larger portion of Islamic instruction that they cannot deliver by themselves at home (Hasan 2009). In such cases, the schools are likely to be income generating machine for the organization that it can operate other more ideological project. For instance, the revenue gained from SMP Luqman Hakim in Surabaya is partly used for operating the Sekolah Tinggi Ilmu Syariah (Islamic Law Academy). Most students of this academy are on full scholarship and are considered as cadres. They are obliged to conduct dakwa mission after their studies there. 
With the current organizational arrangement as a mass organization, the structure of Hidayatullah is led by a general chairman located in the headquarter Jakarta. The central committee manages a range of affairs, from education, dakwa, to asset management, like many other Indonesian mass organizations. The organization has currently 280 branches which represent districts in almost all the country's provinces. ${ }^{3}$ In addition to managing dakwa mission in their areas, every branch manages their important assets which are schools and philanthropy organization called Baitul Maal Hidayatullah (BMH). In this new arrangement, Pesantren Hidayatullah is considered as its most important center for cadre training through its boarding school, university, and dakwa training. Therefore the students in Balikapapan come from all the branches and most of them are the children of the dakwa cadres living there or the local children who are expected to continue Hidayatullah mission in their home communities. The organization's spiritual leader, Abdurrahman Muhammad, also lives in the pesantren complex. Thus, it is clear that even the central office of the organization is located in Jakarta, its spiritual center remains in Balikpapan.

In addition to pesantren-like learning model, the educational arrangement in the pesantren is delivered through formal schooling from primary to university level. As part of building dakwa militancy, the final year students of its high school are obliged to carry out dakwa mission in designated locations for a year before they are given their certificate. The same obligation is also required for those graduating from the university level, but for longer time. During the mission, they are required to deliver any kind of dakwa method at least 25 times in a month. It can be delivering sermon to adults, teaching Al Qurán to children or home visit to some local villagers. ${ }^{4}$

3 There are currently 415 municipalities and 93 districts situated within 34 provinces in Indonesia. http://otda.kemendagri.go.id/index.php/data-otda/dataprovkabkota.

4 An interview with Basori. Balikpapan, 23 July 2013.

DINIKA, Volume 3, Number I, January - April 2018 


\section{The Hidayatullah in Balikpapan}

Nowadays, Balikpapan remains the most important place for this organization due to the historical and strategic reasons. It is where Abdullah Said started the mission from a very small number of followers, where they put the dream of ideal Muslim umma into reality, and where the movement attracted a huge number of followers for the first time. In today's strategic view of Hidayatullah, Balikpapan is where they prepare the dakwa cadres before being posted throughout the archipelago up to now. It is where they received the largest fund from the community. The organization also holds its annual meeting there with around 5,000 participants from all branches throughout the archipelago.

In Balikpapan, Hidayatullah has several important institutions. The first is the the complex of the pesantren in Gunung Tembak on more than 50 hectares where the Islamic boarding school, dormitory, university and Islamic dwellings are located. The school ranges from kindergarten to university and a special program of Quránic memorization. There are about 200 teachers and staffs in all the schools. The second institution is the Dakwa Training Centre in Karang Bugis in the inner city of Balikpapan. In this place, the organization conducts a regular three-month or a year dakwa course for about 25-30 potential cadres sent from branches throughout the country. Karang Bugis is historically important because it is where Abdullah Said started his sermon before moving to Gunung Tembak. In addition, Hidayatullah also owns a junior high school (SMP) in the inner city. This school targets children from the middle and affluent class families living in the Balikpapan city with an expensive tuition fees and offers a high quality education. The school was founded nine years ago, and only within three years it had generated profit. The profit then transferred to the pesantren in Gunung Tembak as what they called cross subsidy because the pesantren's students mostly come from the lower class. The third institution is the office of BMH in Balikpapan CBD. Although 
it is part of the national brand of BMH headquartered in Jakarta, the Balikpapan office is the strongest in term of the amount of fund they are able to collect from the community. In the year of 2012, it collected about Rp. 12.000.000.000,-. This is the largest amount compared to the amount collected by other branches.

In term of the dakwa range, Hidayatullah holds mosque management in 100 mosques throughout Balikpapan. With this authority, they can take decision on the mosques' programs, the preachers, and collect almsgiving from the congregation. During the interview with the researcher, the pesantren's director confessed that there is a fierce competition to hold mosque management in the region as many other Islamic groups are also eager to occupy or take over the position. The rivalry is due to the fact that most of the congregations in Balikpapan are financially affluent especially in the mosques that are situated, or owned by, in large companies such as the state-owned petroleum industry Pertamina or the multinational petroleum company Total. The affluent congregation means huge almsgiving potentials. So there is an intertwining competition for both religious authority and alms-giving fund. Many locals from various backgrounds and social classes that I encountered agreed that Hidayatullah is the most influential Islamic movement in the city, especially among blue collar workers of large companies because almost all mosques in their workplace are managed by Hidayatullah cadres.

\section{Efforts to Run Revenue-Generating Businesses}

Hidayatullah has realized the importance of generating money for financing their education and dakwa activities. Sujaib who had been involved in various economic projects conducted by Hidayatullah since late 1980s shared the story. His first encounter to this group was in late 1980s when he was accepted as an employee in Hidayatyullah cooperative located in the inner city of Balikapapan. The cooperative was founded as

DINIKA, Volume 3, Number I, January - April 2018 
an aspiration of Hidayatullah congregation as the number of attendants in the weekly sermon by the late Abdullah Said increased considerably. The fact that many of them needed to buy water, food, or sermon handbook had inspired them to establish a cooperative which sell groceries and books. It run for several years up to the mid of 1990s, and eventually collapsed due to huge unpaid debt by consumers. In early 1990s, when the cooperative still operated, Sujaib was given a new responsibility to manage a chicken farming. The business had reached its peak by producing 1,000 chickens a day. It was the largest chicken farming in East Kalimantan province. Eventually it could not survive when Indonesia was hit by monetary crisis in 1997-98. ${ }^{5}$

Until now, Sujaib and his colleagues in the economic division remain struggling to find out feasible as well as profitable economic projects. The economic project that survives up to now is what they call as Integrated Farming. Within the project that is located on 60 hectares land are cow and sheep livestock, fish farming, rubber plantation (15 hectares), and pecan plantation (2,000 trees). The cow livestock receives support from Indonesian Ministry of Agriculture's program of LM3. ${ }^{6}$ There are

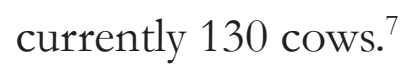

The pesantren also founded two brands of Islamic credit and saving business (BMT, Baitul Maal wat Tamwil), named BMT Bina Mandiri and BMT Bina Sejahtera. The former grows better with asset over 1 billion rupiah than the latter. Both brands have only an office respectively to serve customers. Their market penetration is limited in Balikapapan region.

In addition, there is a grocery store named Sakinah Mini Market in the pesantren's front yard. The store has just operated few months before my visit there. Sakinah is a revival of many similar businesses that had

5 Interview with Sujaib. Balikpapan, 20 July 2013.

6 Sebuah buku laporan program yang dikeluarkan oleh Badan Penyuluhan dan Pengembangan Sumber Daya Manusia Pertanian, 2012.

7 Interview with Pesantren Director. Balikpapan 20 July 2013. 
collapsed. The fail of such business was believed to be because of unpaid debt by consumers that were the Hidayatullah congregation. The previous store did not use computerized cashier which created opportunities for consumers to buy goods without cash payment. In order to avoid the same problem, Sakinah uses computerized cashier by which the consumers have to pay in cash before carrying out the goods. It is a relatively new model in small-medium scale retail business in Indonesia.

In order to build a sense of belonging among the Hidayatullah community, Sakina was built on a cooperative organizational model. It was started with 115 million rupiah capitals which was coming from the pesantren foundation (51 percent), the 16 halaqah groups which are organized in the pesantren's mosque (24 percent), and the school institutions in the complex (25 percent). Soon before the opening, the pesantren director asked a cadre who has been involved in the same business in Surabaya to become its manager. The retail business owned by Hidayatullah East Java region is known the most successful and has evidently contributed to finance the organization. Therefore, Hidayatullah Balikpapan asked one of its managers to lead the newly founded Sakinah.

During interview with me, the newly appointed manager raised some disappointments regarding the amount of the capital fund and the store building arrangement. According to him, the minimum capital for operating such store should have been Rp 250.000.000,-. With only a half of that amount, he felt difficult to boost its business performance. More than that, the arrangement of store building, in his view, is very vague. The store does not face up to, and situated too far from, the main road, so the travellers cannot recognize it. Furthermore, there is a rule in Hidayatullah community that women are not allowed to come to the store. Instead, they will open another store next to the already existing one for womenonly consumers. In the manager's opinion, this plan will create double burden on the investment cost because he has to build another store to

DINIKA, Volume 3, Number I, January - April 2018 
sell the same goods and pay more staffs. With the same potential market, therefore, Sakinah has to spend double investment.

\section{Mobilizing the Public Funds: Baitul Maal Hidayatullah (BMH)}

Compared to the income-generating projects discussed above, the funds gained from the public through Hidayatullah philanthropy organization, Baitul Maal Hidayatullah (BMH), is much more significant in term of amount. BMH has officially operated since 2001 with an approval from the Ministry of Religious Affair (Decree of the Ministry of Religious Affair No. 538, year 2001). It currently has 43 branches and 190 service outlets throughout the country. Among the branches, the Balikpapan branch is the strongest as it is able to collect the largest amount of almsgiving from the public.

It is obviously understandable because the presence of Hidayatullah with its dakwa mission has been there since early 1980s. As mentioned above, the backbone of Hidayatullah mission to the grass root is through the occupation of mosque management. With 100 mosques including those located within corporation complex, the BMH staffs found easier ways to introduce the organization profile, programs and available options to contribute.

The manager of its Balikpapan branch said that there are some strategies in the fundraising. The first strategy is by giving sermon on the importance of delivering alms-giving. The topic can be delivered in mosques on the routine schedule, the regular Friday sermon, daily or weekly Islamic study group (pengajian/halaqoh), or on a special session. Such sermon is commonly delivered by Hidayatullah dakwa cadres, not the BMH staffs. It is commonly explained from Islamic law principles in which each Muslim is obliged to pay zakat fitra once a year and should be paid by the coming of Idul Fitri. When Muslims have wealth reaching a nishob (minimum amount to be compulsory for zakat), they must pay rakat 
maal amounted of $2.5 \%$ of his total assets once a year. In this case, the payment can be done monthly in order to avoid the feeling of hardship. In addition, there are some voluntary donations called infaq and sadaqab that can be done anytime and on any amount.

When a community group has been addressed with a sermon on this topic, BMH staffs normally follow up by the second strategy. It organizes a special session in which Hidayatullah's staffs are ready with screen projectors, presentation slides, brochures, and auto debit forms. The session is normally started by persuasive approach and comprehensive explanation about where the money collected by BMH is distributed. Then, it is finally closed by providing some options to contribute to the $\mathrm{BMH}$ : monthly auto debit, yearly payment, once-off donation, or contributing to a special program such as scholarship and economic empowerment.

In 2013, BMH Balikpapan branch received Rp. 12.000.000.000,(AUD 1,200,000). There are around 20,000 bank accounts that are registered for monthly auto debit. The amount debited ranged from Rp. 50.000 ,- to Rp. 1.000.000,- every month. By the coming of Ramadan, BMH staffs distributes infaq cards, in the form of empty envelops. The congregation of all Hidayatullah affiliated Islamic activities are expected to send the envelopes back after filling them with money. In Ramadan 2013, there were 20.000 infaq cards that were sent back by the congregation.

\section{Financing Education and Dakwa}

In accordance with Hidayatullah's main focus on education and dakwa, most of the funds raised through $\mathrm{BMH}$ and other projects are used for financing these activities. In general, most of the funds used for financing the operation of the pesantren in Balikpapan and its schools through scholarship scheme as well as direct incentive to the institution. Meanwhile, the other significant amount is allocated for financing dakwa mission by providing transportation and living cost for the deployed cadres.

DINIKA, Volume 3, Number I, January - April 2018 


\section{Educating Dakwa Cadres}

The fund for education is allocated through several programs, such as Leadership School Scholarship (Beasiswa Sekolah Pemimpin), Berkah Scholarship, Dakwa Cadre Scholarship, and Firm Teacher (Guru Tangguh).

The Leadership Scholarship is the largest proportion among other scholarship projects. The Pesantren Hidayatullah has now around 1,400 students, and about 60 percent of them receive full scholarship through this scheme. It means that their tuition fees, accommodation and meal cost are covered through this scheme. Those who receive this scheme are mostly the children of Hidayatullah cadres who are posted in faraway areas and children from villages that become targeted areas of Hidayatullah dakwa mission. The reason behind this scheme is to create future ideologist generation of dakwa cadres from the families who have been part of Hidayatullah. The children will be the second or third generation of this movement. Another reason is to make sure that all cadres who are in the dakwa mission are able to provide good quality education for their children in spite of their hardship in earning money. Children from targeted villages sent to the Pesantren in Balikpapan on this scholarship scheme are expected to be the future dakwa cadre in their home village that will find easier to engage with their own community.

Meanwhile, Berkah Scholarship is allocated for children of local poor families in Balikpapan areas. It is a supplementary fund for school children on different amounts. Students of primary school are given Rp. 100.000,- per month, of secondary school are given Rp. 150.000,- per month, and of high school are given Rp. 200.000,- per month. During the fieldwork, there were 300 children received this scheme. This scheme, according to Basori, the BMH manager of this program, is intended to reach local communities with the benefit of the Hidayatullah existence in their area. The beneficiaries are ideally sent to Hidayatullah schools, but in reality not all children and parents are happy to follow this direction. 
There was a story of a beneficiary named Rijal, a child of a Maduranese single mother. He was the recipient of Berkah Scholarship for his school in other Pesantren. It is Nahdlatul Ulama affiliated pesantren. Someday Rijal gave up his school there for an unknown reason. Then, Basori approached Rijal's mother to send him to Pesantren Hidayatullah for free of charge or without paying tuition fees, but she rejected the offer. Her reason was that if Rijal lives at home and goes to nearby school; he could help her doing household and other jobs. ${ }^{8}$ I was curious with this information. I suspect that Rijal's mother refusal was not merely based on practical reason as she claimed, but she actually had an ideological constraint to send his child to Pesantren Hidayullah. It is known that Maduranese are likely to be followers of Nahdlatul Ulama stream of Islam, while Hidayatullah has been recognized widely as referring to wababi stream. Unfortunately I was unable to reach Rijal's mother during my fieldwork in Balikpapan.

The third program supporting educational program is Dakwa Cadre Scholarship. It is a funding scheme for those who want to study at the Hidayatullah higher educational institution called Sekolah Tinggi Ilmu Syariah (STIS, Academy for Islamic Law) situated within the pesantren complex. All students in this academy are on this scholarship scheme, so they do not need to pay any fee at all. The students are mostly recommended or proposed by Hidayatullah's regional chapters as they are expected to be the movement cadre in the future. In addition to topics that are found in other similar academy, they are also given many more materials related to Hidayatullah's ideology and school of thought. When they finish their study for about four years, they are then obliged to carry out dakwa missions in designated locations. The duration of this posting depends on the instruction from the central board of the organisation. Many of them are arranged for marriage before the posting.

$8 \quad$ An interview with Basori. Balikpapan, 19 July 2013.

DINIKA, Volume 3, Number I, January - April 2018 
This annual marriage arrangement is an important rite de passage by which the organization can maintain as well as broaden its networks. Before the graduation, every student of STIS is asked whether he/she wants or ready to get married. If they are ready, they are asked to register to a special committee handling this program. Both boys and girls fill the application form which describes their personal history and academic achievements. They are then interviewed by the committee. An informant who was involved in the committee told me that the committee tried to gather information as much as possible from various sources about every single applicant of this program, from physical appearance, family background, to strengths and weaknesses of their personality. This job is not too hard as most members of the committee are their teachers and mentors who live in the same pesantren complex for several years. Based on this information, the committee then starts to pair the boys and girls. They try to match the pairs in balance of their physical appearance, socioeconomic status of their family, academic performance, and many other considerations. This is as to comply with Islamic guidance in marriage which suggests a balanced pairing. Finally, all couples are then arranged to have a marriage inauguration about a month before Hidayatullah's annual gathering in the pesantren. In 2013, there were 50 couples participated in this arranged marriage project. In the end of the gathering, there is an announcement about where each couple will be delegated for dakwa mission. Graduation from their school, getting a marriage, and being delegated to a dakwa mission are likely to be a complete process for a real Hidayatullah dakwa cadre.

The last program supporting educational program is Firm Teacher (Guru Tangguh). It is a supporting fund for some teachers who teach in the Pesantren Hidayatullah schools as a complementary to their salaries from the schools. Regardless of the school routine as teachers, they have to do many dakwa activities. As a consequence, they have no time to earn 
more money from other sources. They receive a monthly salary between Rp. 700.000,- to Rp. 1.000.000,-. The amount is estimated insufficient for covering their living cost. Therefore BMH provides them with complementary fund around Rp. 500,000 per month. There were about 70 teachers receiving this fund.

\section{Financing Dakwa Outreach}

Dakwa Outrech is the other main concern of Hidayatullah. Therefore $\mathrm{BMH}$ allocates its second largest portion of fund to finance dakwa mission. There are three main programs in this area that are Autonomous Preacher Training (Kuliah Dai Mandir), Targeted Areas (Daerab Binaan), and Firm Preacher (Dai Tanggub).

Given the fact that many of its dakwa cadres scattered throughout the archipelago are not generated through the normal of flow of its educational arrangement, Hidayatullah arranges a one-year dakwa training called Kuliah Dai Mandiri (Autonomous Preacher Training). In this program, Hidayatullah dakwa cadres often recruited new cadres from local targeted communities. The new cadres are often not school-aged-children but adults and often married men, so it is impossible for them to attend the formal schools. When they are seen as promising cadres to continue the mission in their local community, the Hidayatullah's cadres could recommend them to join this one-year training. It is aimed to provide basic Islamic knowledge and build dakwa militancy based on Hidayatullah's Islamic vision.

The training is conducted in the Hidayatullah Dakwa Centre, located in Karang Bugis, the location where Abdullah Said started his sermon for the first time in late 1970s. The site is equipped with mosque, class rooms, dormitories and other Hidayatullah's assets. The participants of the training are required to live in the dormitory for the whole period of the program. Their numbers are from 25 to 30 people in every batch. All

DINIKA, Volume 3, Number I, January - April 2018 
their travel expenses, living and education cost are covered by the $\mathrm{BMH}$ through the Autonomous Preacher Training scheme.

The second program allocated to support dakwa outreach is what they call Targeted Regions (Daerah Binaan). This program is managed by Dakwa Division of Hidayatullah board, but the full funding comes from the BMH. In Balikpapan area, the number of dakwa cadres that are receiving fund through this scheme are 100 people. They are posted in both rural villages and urban neighbourhood as targeted areas. Not all dakwa cadres receive this funding scheme as some of them are able to earn livelihood by themselves. Therefore, their eligibility is assessed regularly. The main point in Hidayatullah's policy regarding dakwa cadre in mission is that their main task is to conduct dakwa activities, and earning livelihood should be secondary to their dakwa activities. This funding scheme is aimed to support their living cost that they can focus on dakwa activities.

One of the examples of this program is located in a village nearby Kutai Kartanegara district. It is a village where most of its inhabitants are elderly people who were stigmatized to be linked to the Indonesian Communist Party (PKI). During the $1965-66$ political outrage, anyone suspected to be members or sympathizers of PKI became the massacre targets (Roosa 2006), and some of them found a sanctuary in this remote village surrounded by forest. Today, all of them have been over 65 year old. Hidayatullah have listed the village as its Targeted Regions for more than ten years with a mission to spread Islam to the inhabitants. It has been known that most members of the Communist Party were from less religious stream of Indonesian society. Therefore, Hidayatullah preachers tried to convert those who had not been Muslims and to deepen their Islamic religiosity for those who had been Muslims. However, this is not typical village where Hidayatullah conduct the Targeted Regions project. The fit-for-all criteria of this program are the need to spread Islamic messages in that area and the available opportunity for Hidayatullah to carry out dakwa mission there. 
The other funding scheme is Firm Preacher (Dai Tanggub). This is part of the Hidayatullah national program sends dakwa cadres throughout the country, from Aceh to Papua. The dakwa cadres under this scheme must live in their designated area and engage in daily Islamic activities of the local community. There is a quantitative benchmark that they are required to conduct at least 25 or 30 activities within a month. The activities can be teaching Al Qurán recitation, teaching Islamic subjects in local schools, giving sermon in Islamic study groups, or conducting door-to-door homevisit-dakwa. There are currently hundreds of preachers who receive this funding scheme. Nevertheless, BMH Balikpapan didnot explain the exact number of the funding as it is distributed by the Central Committee of the organization.

\section{Providing Health and Social Services}

Unlike other charitable organizations which commonly regard health and social services as important fields, $\mathrm{BMH}$ seems to put a very little attention to these issues. Among other things they have done in this field is to have one ambulance car which can be used by the needy for free. By the coming of Ramadan, BMH organizes a free health check for pregnant and elderly women. The other regular event is organizing a collective circumcision as part of its annual national gathering agenda.

\section{Conclusion}

This article has shown that Pesantren Hidayatullah in Balikpapan has successfully raised public fund through $\mathrm{BMH}$ for financing its education and dakwa mission. There is an interdependence relationship between its development in managing educational institutions, conducting dakwa outreach, and collecting public fund. It can be said that what they do is persuading congregation to donate some money then the money is used for Hidayatullah's prioritized agenda: education and dakwa. From critical

DINIKA, Volume 3, Number I, January - April 2018 
point of view, there is no significant allocation for community welfare through health services or economic empowerment projects because these issues are not their priorities.

\section{References}

Azra, Azyumardi, Dina Afrianty, and Robert W. Hefner. 2007. "Pesantren and Madrasa: Muslim Schools and National Ideals in Indonesia." In Schooling Islam: The Culture and Politics of Modern Education, edited by Robert D. Hefner and Muhammad Qosim Zaman, 172-98. Princeton: Princeton University Press.

Damopoli, Muljono. 2011. Pesantren Modern IMMIM: Pencetak Muslim Modern. Jakarta: Rajawali Pers.

Hasan, Noorhaidi. 2009. Islamizing Formal Education: Integrated Islamic School and a New Trend in Formal Education Institution in Indonesia. Singapore: S. Rajaratnam School of International Studies.

Hefner, Robert W. 2009. "Islamic Schools, Social Movements, and Democracy in Indonesia." In Making Modern Muslims: The Politics of Islamic Education in Southeast Asia, edited by Robert W. Hefner, 55-105. Honolulu: University of Hawaii Press.

Husin, Asna. 1998. "Philosophical and Sociological Aspects of Da'wah: A Study of Dewan Dakwah Islamiyah Indonesia." Columbia University.

Isbah, M. Falikul. 2012. "Religiously Committed and Prosperously Developed: The Survival of Pesantren Salaf in Modern Indonesian Islamic Education." Review of Indonesian and Malaysian Affairs 46 (1): 83-104.

Jackson, Elisabeth and Lyn Parker. 2008. "'Enriched with Knowledge': Modernisation, Islamisation and the Future of Islamic Education in Indonesia."." Review of Indonesian and Malaysian Affairs 42 (1): 21-53.

Latief, Hilman. 2012. "Islamic Charities and Social Activism: Welfare, Dakwah and Politics in Indonesia." Utrecht University. 
Roosa, John. 2006. Pretext for Mass Murder: The September 30th Movement and Subarto's Coup d'Etat in Indonesia. University of Wisconsin Press.

DINIKA, Volume 3, Number I, January - April 2018 